\title{
Hogyan ellenőrzi az immunrendszer a daganatok kialakulásának és növekedésének folyamatát?
}

\author{
Sütő Gábor dr. \\ Pécsi Tudományegyetem, Klinikai Központ, Reumatológiai és Immunológiai Klinika, Pécs
}

\begin{abstract}
Az immunrendszer feladata a szervezet integritásának megőrzése. Az immunrendszer elemei egy sokrétű, a legkülönbözőbb módon összekapcsolódó hálózatot képeznek. Ennek múködése biztosítja a külső és a belső környezetből származó információk alapján a legmegfelelőbb immunválaszt a fertőzések és a daganatképződés ellen. Az immunválasz diszfunkciója számos betegséghez vezet, beleértve a daganatképződést és a krónikus gyulladásos betegségeket. Az immunhálózati csomópontok immunbiológiai befolyásolása új terápiás lehetôségeket nyitott mind a reumatológiai, mind a daganatos betegségek kezelésében. A gyulladásgátlás mellett fokozni lehet az immunrendszer daganatellenes aktivitását. Ezáltal olyan malignus betegségek kezelésében javultak az eredmények, amelyek korábban nem voltak sikeresen gyógyíthatók. Orv. Hetil., 2016, 157(Szuppl. 2), 3-8.
\end{abstract}

Kulcsszavak: immunrendszer, daganatnövekedés, immunrendszeri ellenőrző pont, biológiai kezelés

\section{The role of immune system in the control of cancer development and growth}

The role of immune system is the maintenace of the integritiy of the living organism. The elements of the immune system are connected by several ways forming a complex biological network. This network senses the changes of the inner and outer environment and works out the most effective response against infections and tumors. Dysfunction of the immune system leads to the development of cancer development and chronic inflammatory diseases. Modulation of the checkpoints of the immune system opened new perspecitves in the treatment of rheumatological and oncological diseases as well. Beside the potent antiinflammatory activity, new therapies are able to stimulate anticancer activity of the immune system. The result of these recent developments is a better outcome of malignant diseases, which had an unfavorable outcome in the past.

Keywords: immune system, cancer growth, immune checkpoint, biological therapy

Sütó, G. [The role of immune system in the control of cancer development and growth]. Orv. Hetil., 2016, 157(Suppl. 2), 3-8.

(Beérkezett: 2016. április 11.; elfogadva: 2016. április 27.)

Az immunrendszer feladata az ön- és a fajfenntartás biztosításához: 1. a kórokozók elleni védekezés, 2. a kontrollálatlan sejtproliferáció megelőzése és 3 . az elpusztult sejtek, szövetek „eltakarítása”. Erre a feladatra egy komplex rendszer alakult ki, amely behálózza az egész szervezetet. A nemkívánatos molekulák, sejtek, szövetek felismerése mellett az immunrendszer megtanulja a "saját” azonosítását is. Ha ebben a rendszerben hiba keletkezik, akkor alakulnak ki gyulladásos betegségek: autoimmun és immunmediált kórképek, allergia, im- munhiányos állapot, autoinflammatorikus szindrómák, malignus betegségek. Ezek az elváltozások rendszerint nem izoláltan jelentkeznek, egymással sokszor társulnak.

\section{Az immunrendszer elemei}

Az immunrendszert sejtek, sejthez kötött és azoktól függetlenül létező kis molekulák alkotják, amelyek összetettebb struktúrákat, szöveteket, szerveket képeznek. 
A nyálkahártyafelszíneken [1] és a bőrön a fertőzések elleni elsődleges védelmet a fizikális barrier képezi $[1$, 2]. A külvilággal való határfelületeken (bőr, légutak, gyomor-bél rendszer, urogenitális traktus) olyan szöveti szerkezet (elszarusodó hám, csillószőrös vagy csilló nélküli hengerhám, laphám) és védekezőmechanizmusok (keratinizáció, nyáktermelés, perisztaltika, gyomorban és a hüvelyben savas $\mathrm{pH}$ ) alakultak ki, amelyek a kórokozók behatolását meggátolják vagy legalábbis megnehezítik. A fizikális gátat leküzdő kórokozók a természetes („innate") immunrendszerrel találkoznak először, illetve a gerinceseknél kialakul az adaptív immunredszer is, amely sokkal specifikusabb, „finomra hangoltabb” immunválasz kialakulásához vezet.

A természetes immunitás elsősorban a patogének elleni védekezésben játszik szerepet [1] (1. táblázat). A kórokozók felszínén jelen lévő ismétlődő mintázatokat ismerik fel szolúbilis (például komplement) sejtfelszíni (Toll-szerú) és intracelluláris (NOD) receptoraik révén. Ennek eredménye egyrészt a kórokozó közvetlen elpusztítása fagocitózis útján, másrészt kemotaxist mediálnak, valamint további effektor molekulák termeléséhez vezetnek. Ezek a citokinek a természetes immunválaszt erósítik fel, illetve az adaptív immunválasz elindításában, annak szabályozásában vesznek részt. A természetes immunitás receptorai preformáltan jelen vannak, ezért szinte azonnal érzékelik a behatoló kórokozókat vagy azok elemeit. Ebben a rendszerben memóriára nincsen szükség, mivel a felismert mintázatok száma véges, és ezek receptorai egy sejttípus mindegyik sejtjén jelen vannak.

$\mathrm{Az}$ adaptín immunrendszer [3] receptorai a szolúbilis és sejtfelszíni immunglobulinok és a T-lymphocyták receptorai (1. táblázat). Ezek a klonotípusos immunitást képviselik. Antigén hatására szelektálódnak és affinitásérésen mennek keresztül, amelynek eredményeként a kü- lönböző antigénekre elkötelezett szolúbilis és sejtfelszínhez kötött immunglobulinok és T-sejt-receptorok alakulnak ki. Mivel a folyamat időt igényel, ez az immunválasz késleltetve jelenik meg, kialakulásához 7-10 nap szükséges. Ugyanakkor a feldolgozott antigén ellen kialakult válasz hosszabb, és ismételt antigén-expozíció során a memóriasejtek révén gyorsabb és erősebb választ kapunk, mint az első találkozáskor.

A természetes immunrendszer müködése során kapcsolódik az adaptí immunrendszerhez. A természetes immunrendszer antigén-prezentáló sejtjei az MHC-molekulával kapcsolt antigént a megfelelő receptorral rendelkező T helper (Th-) sejt számára felkínálják. A Th-sejt aktivációja nemcsak az antigén-MHC komplex és T-sejtreceptor találkozáson, hanem további kostimulációs molekulák kapcsolódásán is múlik, amelyek mennyisége az antigén hatására aktiválódó antigén-prezentáló sejtek felszínén megnő. Az antigén-prezentáló sejtek $\mathrm{CD}$ 80/86 molekulája az aktivált Th-sejt CD-28 molekulájához kötődik, amely további aktivációhoz vezet [4]. Azonban a folyamat erősítése nem lehet végtelen, megfelelő fék áll rendelkezésre, amely a Th-sejt-aktiváció gátját képezi. A Th-sejtek felszínén egyre több citotoxikus T-lymphocyta antigén (CTLA-4) molekula jelenik meg, amelyek szintén a CD 80/86 molekulához tudnak kötődni. Ez a kapcsolódás azonban már negatív szignált jelent, a sejtaktivitást gátolja, és végső soron az immunválasz lecsengéséhez vezet [4]. A CTLA-4 molekula az immunrendszer múködésére negatívan hat [5]. Csökkent múködése gyulladásos folyamatok és az autoimmunitás felerősödéséhez vezet. Fokozott múködése az immunrendszert gátolja, a természetes immunitásnak az adaptív immunrendszerre gyakorolt serkentőhatását gyengíti, végső soron az infekciók és a tumorok elleni védekezés gyengül.

1. táblázat |A természetes és az adaptív immunrendszer

\begin{tabular}{|c|c|c|}
\hline & Természetes immunitás & Adaptív immunrendszer \\
\hline Előfordulás & Minden élőlényben & Magasabb rendű gerincesek \\
\hline Alkotórészek & Sejtes és szolúbilis & Sejtes és szolúbilis \\
\hline Válasz & Gyors, erőteljes & A maximális hatásosság eléréséhez idő kell \\
\hline Ismételt antigén-expozícióra & Hasonló válasz & Gyorsabb, erôsebb válasz \\
\hline Memória & Nincs & Van \\
\hline Az antigénre adott válasz típusa & Nem specifikus & Specifikus \\
\hline Felismerés & $\begin{array}{l}\text { Patogénekkel asszociált mintázatok: szénhidrát, lipid, } \\
\text { endotoxin, nem metilált CPG-motívum }\end{array}$ & $\begin{array}{l}\text { Immunglobulinok, valamint antigén-prezentáció } \\
\text { során specifikus T-sejt-receptorok révén elsősorban } \\
\text { fehérjék }\end{array}$ \\
\hline Komponensei & $\begin{array}{l}\text { Celluláris komponensek: macrophagok, neutrophil } \\
\text { granulocyták, dendritikus sejtek, hízósejtek, } \\
\text { eosinophilek, basophilek, természetes ölősejtek (NK), } \\
\text { szolúbilis molekulák: komplementrendszer, citokinek, } \\
\text { kemokinek, interferonok, antimikrobiális peptidek, } \\
\text { növekedési faktorok, CRP, szérum-amiloidfehérje, } \\
\text { mannózkötő lektin, prosztaglandinok, leukotriének }\end{array}$ & $\begin{array}{l}\text { Celluláris komponensek: B- és T-lymphocyták, } \\
\text { lymphocyta-alcsoportok: helper, killer T-sejtek, } \\
\gamma \delta \text { T-sejtek, molekuláris elemek: immunglobulinok, } \\
\text { T-sejt-receptorok }\end{array}$ \\
\hline
\end{tabular}




\section{Az immunrendszer mint hálózat}

Az immunrendszer megértése nagyon nehéz, sok tekintetben ma sem ismerjük minden részletét az immunválaszt kialakító folyamatnak. Az immunrendszer múködését tekintve egy több szintből álló hálózatnak tekinthető. 1974-ben Niels Jerne [6] volt, aki legelsőként megfogalmazta az adaptív immunrendszer hálózatos múködési elvét. Az azóta eltelt időszak matematikai és számítástechnika ismereteinek fejlődése révén ma már az emberi szervezetet és ezen belül az immunrendszert egymásra épülő többszintű hálózatként lehet definiálni [7, 8]. Ennek megfelelően az emberi szervezeten belül számos szerv, ezek szövetei és sejtjei, illetve szubtípusai alkotják a hálózatok csomópontjait. Finomabb analízissel a makromolekulák (gének, RNS-ek, proteinek, egyéb metabolitok) hálózata tárható fel. A csomópontokat fizikai (például kémiai reakciók, receptor-ligand kapcsolódás), regulációs és funkcionális kapcsolatok kötik össze. Az élő szervezeten belül számos modul (például komplementrendszer, természetes immunitás, adaptív immunitás) található, amelyek egy-egy funkcióért felelősek. Ezek

\section{2. táblázat $\mid \mathrm{Az}$ immunrendszer receptorai}

\begin{tabular}{lll}
\hline & $\begin{array}{l}\text { Természetes } \\
\text { immunitás }\end{array}$ & Adaptív immunitás \\
\hline $\begin{array}{l}\text { Felismert patogének } \\
\text { típusa }\end{array}$ & Nagyszámú & Specifikus felismerés \\
\hline Molekuláris diverzitás & $\begin{array}{l}\text { Sokféle hasonló } \\
\text { molekula }\end{array}$ & Specifikus felismerés \\
\hline Időbeliség & Gyors & Lassú \\
\hline Lokalizáció & $\begin{array}{l}\text { Egy sejttípus minden } \\
\text { sejtjén }\end{array}$ & Klonális expanzió \\
\hline $\begin{array}{l}\text { Lokalizáció a } \\
\text { genomban }\end{array}$ & $\begin{array}{l}\text { Egy gén határozza } \\
\text { meg }\end{array}$ & $\begin{array}{l}\text { Több gén } \\
\text { átrendeződésével jön } \\
\text { létre }\end{array}$ \\
\hline Klonalitás & Nincs jelen & Jellegzetes \\
\hline
\end{tabular}

3. táblázat |A humorális immunrendszer effektor folyamatai

\begin{tabular}{lll}
\hline & Funkció & Élettani szerep \\
\hline Antitestek & Neutralizáció & Toxinok, mikrobák \\
\cline { 2 - 3 } & Opszonizáció & $\begin{array}{l}\text { Mikrobák } \\
\text { fagocitózisának } \\
\text { elősegítése }\end{array}$ \\
\cline { 2 - 3 } & $\begin{array}{l}\text { Antitestfüggó } \\
\text { celluláris citotoxicitás }\end{array}$ & Célsejt lízise \\
\hline Komplementrendszer & Lízis & Mikrobák lízise \\
\cline { 2 - 3 } & Opszonizáció & $\begin{array}{l}\text { Mikrobák } \\
\text { fagocitózisának } \\
\text { elősegítése }\end{array}$ \\
& $\begin{array}{l}\text { Kemotaxis, C3a, } \\
\text { C4a, C5a bazofil sejt } \\
\text { degranulációt okoz }\end{array}$ \\
\cline { 2 - 3 } & Gyulladás & \\
&
\end{tabular}

4. táblázat $\mid$ A természetes és adaptív immunrendszer celluláris effektor folyamatai

\begin{tabular}{llll}
\hline & Sejttípus & $\begin{array}{l}\text { Jellegzetes } \\
\text { citokinek }\end{array}$ & $\begin{array}{l}\text { Élettani szerep } \\
\text { - védelem }\end{array}$ \\
\hline 1-es típus & $\begin{array}{l}\text { TH1, ILC1, } \\
\text { TC1, NK }\end{array}$ & $\begin{array}{l}\text { Interferon- } \gamma, \\
\text { limfotoxin- } \alpha\end{array}$ & $\begin{array}{l}\text { Intracelluláris } \\
\text { mikrobák }\end{array}$ \\
\hline 2-es típus & TH2, TC2, & IL-4, IL-5, & $\begin{array}{l}\text { Férgek, mérgek, } \\
\text { káros } \\
\text { xenobiotikumok, } \\
\end{array}$ \\
& ILC2 & IL-13 & $\begin{array}{l}\text { környezeti } \\
\text { irritánsok }\end{array}$ \\
& & & $\begin{array}{l}\text { Extracelluláris } \\
\text { baktériumok és } \\
\text { gombák }\end{array}$ \\
\hline 3-as típus & TH17, TC17, & IL-1, IL-17, & IL-22, IL-23 \\
& ILC3 & &
\end{tabular}

$\mathrm{IL}=$ interleukin; ILC = természetes lymphoid sejt; NK = természetes ölősejt; TC $=\mathrm{CD} 8+$ citotoxikus lymphocyták; $\mathrm{TH}=\mathrm{CD}+\mathrm{T}$ helper lymphocyták.

elemei gyakran átfedik egymást, illetve az egyes modulok befolyásolják egymás múködését [7].

A hálózatnak van „bemeneti” oldala, amelyet a természetes és adaptív immunrendszer különböző receptorainak aktivációjából származó információk képeznek (2. táblázat). A hálózatnak van egy „kimeneti” oldala, amelyet az effektor folyamatok képeznek. Habár élesen nem választhatók szét, az effektor mechanizmusok lehetnek egyrészt molekuláris szintűek, amit a humorális immunitás képez (3. táblázat). Idetartozik a komplementrendszer aktivációja, valamint az antitest mediálta folyamatok. Másrészt a természetes és adaptív immunrendszer együttmúködése hozza létre a sejtes immunválasz három típusát (4. táblázat) [9]. Mindegyik típusban az effektor sejtek (T-helper/T citotoxikus és a természetes lymphoid sejtek) azonos transzkripciós faktorokra reagálnak, hasonló ciktokintermeléshez vezetnek, és ez a háromféle, mintegy előre programozott immunválasz a lehető legoptimálisabb stratégia a szervezet részéról a különböző patogénekre adott válaszra [9].

A receptoriális és a végrehajtó folyamatok között számos regulációs lépés történik, amelyek a beérkező információk alapján az immunválasz mértékét és minőségét határozzák meg. Az immunrendszer válaszát ezen a ponton számos nem immuneredetü tényező is befolyásolja: hormonok, az idegrendszer, táplálkozási faktorok, gyógyszerek módosítják a végeredményt. Az immunválasz eredménye végső soron a patogén eliminációja vagy hatástalanítása, tumorellenes védekezés lesz.

$\mathrm{Az}$ immunrendszer hálózatos elvéból következően vannak szabályok, amelyek meghatározzák a múködést [7]. Egy-egy csomóponti elem múködésének megváltozása tovaterjed az egész immunrendszer múködésére a hálózati kapcsolatok révén. Egy mutáció nemcsak az adott gén múködését módosítja, hanem az interakcióban lévő gének aktivitását. Mindezek alapján egy betegség kialakulása több patobiológiai folyamat interakciójának következménye [7]. 
Tumorantigén bemutatás gátlása
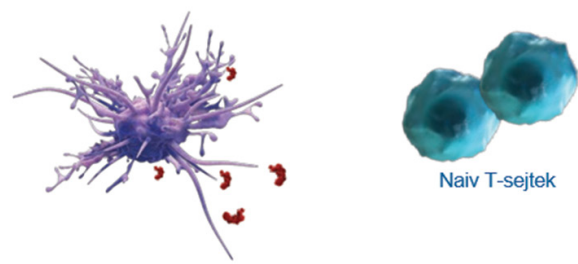

Immunszuppresszív faktorok kiválasztása

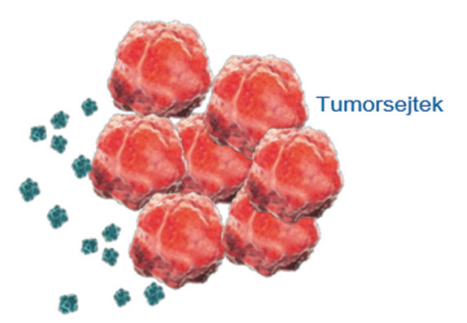

Immunszuppresszív sejttípusok toborzása

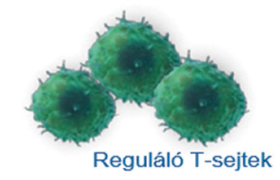

A T-sejtek általi támadás gátlása

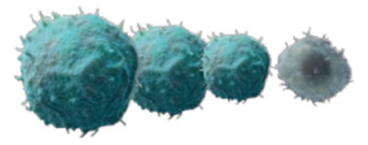

T-sejtek

1. ábra

A tumorok egyszerre több eltérő mechanizmust is alkalmazhatnak az immunrendszer gátlására [28]

\section{Az immunrendszer daganatok elleni védekezése}

A daganat a szervezet sejtjeinek kontrollálatlan szaporodása, amit a környezetre való ráterjedés, valamint távoli helyekre történő propagáció, áttétképzés jellemez. Az immunrendszer egyedüli feladatának sokáig a daganatsejtek elpusztítását gondoltuk, de a közelmúlt új ismeretei megmutatták, hogy az immunrendszer a tumorok propagációját is elôsegítheti, valamint közremúkiödhet a daganatok túlélésében [10] és a terápiás sikertelenség kialakulásában. A daganatellenes immunválasz kialakulásában mind a természetes, mind az adaptív immunitás részt vesz [11]. A daganatokat immunsejtek infiltrálják, amelyek mind pozitív, mind negatív irányba befolyásolják a túlélést. A daganaton belül egyrészt olyan mikrokörnyezet alakul ki, amely elősegítheti a tumor propagációját ( 1 a ábra). Az immunrendszer másrészt gátolni próbálja a daganatnövekedést. Citotoxikus T-lymphocyták (CTL-ek) keletkeznek, amelyek lízis, apoptózisindukció, citokinfelszabaduláson keresztül ölik meg a tumorsejteket [11]. Ebben a folyamatban lényeges a T-sejt-receptor általi antigén-felismerés mellett a kostimuláció, az antigén-prezentáló sejt CD 80/86 antigénje kapcsolódik a CTL CD-28 molekulájához [12]. A folyamatot a CTLA-4 molekula állítja meg, amely az aktivált CTL felszínén jelenik meg, és ellenkező irányú szignali- zációval az antigén-prezentáló sejtek múködését gátolja $[12,13]$. Emellett létezik egy másik erős negatív szignalizációs faktor, a programozott sejthalál-1 (PD-1) receptor, amely szintén az aktivált CTL-sejtek felszínén van jelen $[14,15]$. Két, a tumorsejtek felszínén is expresszálódó ligandja (PD-Ll és PD-L2) [16] van, amelyek kapcsolódása a PD-1 receptorhoz hozza létre a gátlást [14]. Emellett egyéb faktorok is jelen vannak, amelyek szintén immunszuppresszióhoz vezetnek: myeloid eredetú szuppresszor sejtek, regulatorikus T-sejtek, funkcionálisan károsodott DC-sejtek. A Treg-sejtek többféle mechanizmussal gátolják az immunválaszt $[17,18]$ : 1 . inhibitoros citokin (IL-10, TGF- $\beta$ ) -szekréció, 2. metabolikus destrukció: a DC-sejtek éréséhez szükséges extracelluláris IL-2 és adenozinlebontás, 3. cytolysis: granzime A és $\mathrm{B}$, perforin segítségével, 4. CTLA-4- és PD-L1-expreszszió: DC és TCL gátlása. A CTL-ek aktivitását végső soron a serkentő-gátló hatások összegződése szabja meg.

\section{Az immunterápia}

Az immunrendszerre ható beavatkozások négy fó csoportba oszthatóak [19]: antitestek és fúziós fehérjék, citokinek, vakcinák, adoptívsejt-transzfer (5. táblázat). Az immunrendszer hálózatos múködésének elvéből következően egy betegséget egy támadáspontú gyógyszerrel nem lehet teljes mértékben gyógyítani, mivel az információ a hálózat más összeköttetésein, alternatív utakon is eljut. Ugyanakkor egy hálózati csomópont vagy két hálózati elem közötti interakció befolyásolása távoli elemek múködésére is befolyással bír [7]. Ezek a szabályok gyakorlati következményekkel járnak:

1. Több ezer, különböző támadáspontú gyógyszert vizsgáltak és fognak vizsgálni a fejlesztők, de ezek közül csak néhány jut el a gyógyszertárak polcaira. Azokból a fejlesztésekből lehet gyógyszer, amelyek olyan pontokon

5. táblázat $\mid \mathrm{Az}$ immunrendszer működésének befolyásolása

\begin{tabular}{lll}
\hline & Példa & Felhasználási terület \\
\hline $\begin{array}{l}\text { Antitestek és } \\
\text { fúziós proteinek }\end{array}$ & Citokingátlás, & Onkológia \\
& receptorgátlás, & és reumatológia \\
& ADCC indukálása, & \\
& kostimulációgátlás, & \\
& toxinok sejthez kötése, & \\
& tumor- és & \\
& stromainterakció & \\
& befolyásolása, & \\
& $\begin{array}{l}\text { tumor-mikrokörnyezet } \\
\text { ellenórzó pontjának }\end{array}$ & \\
& gátlása & \\
\hline Vakcina & $\begin{array}{l}\text { Tumorasszociált } \\
\text { peptid, tumorsejt, }\end{array}$ & Onkológia \\
& DNS-szekvencia & \\
\hline Citokinek & IL-2, IFN- $\alpha$, GMCSF & Onkológia, \\
& & reumatológia \\
\hline Adoptív transzfer & Aktivált lymphocyták & Onkológia \\
\hline
\end{tabular}


hoznak létre gátlást, amelyek a betegség szempontjából jelentősek, illetve a gátlás mértéke nem vezet súlyos következményekhez, mint például infekciók, másodlagos daganatképződés.

2. A legtöbb gyulladásos kórképben nem lehet teljes remissziót elérni, sokszor be kell érnünk alacsony betegségaktivitással. A rheumatoid arthritisben vagy arthritis psoriaticában akár hagyományos, akár biológiai DMARD-kezelést alkalmazunk, a remisszió elérése nem mindig sikerül, gyakran be kell érnünk a betegség mérsékelt aktivitásával.

3. A gyulladásos reumatológiai kórképek kezelése során gyakran nézünk szembe másodlagos hatástalansággal, amely egy sokszor hosszabb, hatásos időszak után következik be. Ez a biológiai kezelések alkalmazásakor gyakran előfordul és a nem kívánt hatások mellett a tartós gyógyszeradás egyik legnagyobb korlátja [20, 21]. A jelenség hátterében sokszor gyógyszerellenes antitestképződés áll [21-23]. Azonban a gyógyszer elvesztheti hatásosságát úgy is, hogy gyógyszerellenes antitest nem alakul ki. Ennek oka az immunrendszer hálózatos múködéséből fakad. Megerősödnek olyan kapcsolatok, amelyek megkerülik az adott gyógyszer támadáspontját. Ilyen esetben célszerű más támadáspontú gyógyszerre váltani.

4. Az immunrendszer múködésének serkentése nehéz, kevés eszköz állt eddig rendelkezésre. Az adjuvánsokat régóta alkalmazzuk a védőoltások mellé, amelyek feladata, hogy az adaptív immunválaszt a természetes immunrendszer stimulálásával fokozzák. Az immunrendszer hálózatában azonban vannak gátló jellegű kapcsolatok, amelyek kulcsfontosságú ellenőrző pontként szerepelnek. Ezek feloldása a hálózat, illetve annak bizonyos moduljaira serkentőleg hathat, így lehet stimulálni az immunhálózat múködését [24-26]. A CTLA-4 molekula gátlása ipilimumabbal a Treg-sejtek feszínén gátolja a Treg-sejtek szuppresszor hatását [27]. Ugyanígy a PD1-gátlás nivolumabbal szintén serkentóleg hat az immunrendszerre [28]. A CTL-sejtek felszínén található PD-1 gátlása fokozott effektor funkcióhoz vezet. Mindkét gyógyszert olyan daganatok esetében kezdték alkalmazni, amelyek korábbi terápiára alig reagáltak vagy a kezelés súlyos mellékhatásokkal járt [25]. Az ipilimumab a metasztatikus és nem reszekálható melanomában jelentett áttörést. A nivolumab nemcsak melanomában, hanem nem kissejtes tüdőtumorban is törzskönyvezett indikációval bír, és számos tumortípusban folynak jelenleg is klinikai vizsgálatok. A nivolumab kevesebb nemkívánatos immunrendszer-eredetű eseményt okoz, mint az ipilimumab.

\section{Következtetések}

Az immunrendszer az egész szervezetet behálózza, hogy a fertőzéseket és a daganatokat olyan keretek közé szorítsa, hogy az ön- és a fajfenntartás már ne kerüljön veszélybe. Ennek érdekében olyan szenzoros rendszer ala- kult ki, amely folyamatosan érzékeli a szervezetben bekövetkező változásokat. Az immunrendszer elsősorban a természetes immunrendszer révén azonnal be is avatkozik, ha infekció alakul ki. Emellett az adaptív immunrendszer a természetes immunitásra támaszkodva egy specifikus és hatásos választ dolgoz ki a fertőzésekre és a daganatokra. Az immunológiai hálózat múködésére vonatkozóan egyre több információt nyerünk, amelyek segítségével az immunológiai ellenőrző pontokon specifikusan be lehet avatkozni az immunrendszer múködésébe. Ennek következtében egyre hatásosabb és biztonságosabb kezelést tudunk nyújtani a gyulladásos reumatológiai kórképekben és a különböző daganatokban szenvedő betegek számára.

ONCHU16PR02855-01/ Lezárás dátuma: 2016. március 25 .

Anyagi támogatás: A közlemény a Bristol-Myers Squibb felkérésére és támogatásával készült.

A szerző a cikk végleges változatát elolvasta és jóváhagyta.

Érdekeltségek: A szerzőnek nincsenek érdekeltségei.

\section{Irodalom}

[1] Dwivedy, A., Aich, P.: Importance of innate mucosal immunity and the promises it holds. Int. J. Gen. Med., 2011, 4, 299-311.

[2] McGhee, J. R., Fujihashi, K.: Inside the mucosal immune system. PLoS Biol., 2012, 10(9), el001397.

[3] Alexander, K. L., Targan, S. R., Elson, C. O. 3rd.: Microbiota activation and regulation of innate and adaptive immunity. Immunol. Rev., 2014, 260(1), 206-220.

[4] McCoy, K. D., Le Gros, G.: The role of CTLA-4 in the regulation of $\mathrm{T}$ cell immune responses. Immunol. Cell Biol., 1999, 77(1), $1-10$.

[5] Auchincloss, H., Turka, L. A.: CTLA-4: not all costimulation is stimulatory. J. Immunol., 2011, 187(7), 3457-3458.

[6] Jerne, N. K.: Towards a network theory of the immune system. Ann. Immunol., 1974, 125(1-2), 373-389.

[7] Barabási, A. L., Gulbahce, N., Loscalzo, J.: Network medicine: a network-based approach to human disease. Nat. Rev. Genet., $2011,12(1), 56-68$.

[8] Subramanian, N., Torabi-Parizi, P., Gottschalk, R. A., et al.: Network representations of immune system complexity. Wiley Interdiscip. Rev. Syst. Biol. Med., 2015, 7(1), 13-38.

[9] Annunziato, F., Romagnani, C., Romagnani, S.: The 3 major types of innate and adaptive cell-mediated effector immunity. J. Allergy Clin. Immunol., 2015, 135(3), 626-635.

[10] Dunn, G. P., Bruce, A. T., Ikeda, H., et al.: Cancer immunoediting: from immunosurveillance to tumor escape. Nat. Immunol. 2002, 3(11), 991-998.

[11] Vesely, M. D., Kershaw, M. H., Schreiber, R. D., et al.: Natural innate and adaptive immunity to cancer. Ann. Rev. Immunol., 2011, 29, 235-271.

[12] Brzostek, J., Gascoigne, N. R., Rybakin, V.: Cell type-specific regulation of immunological synapse dynamics by B7 ligand recognition. Front. Immunol., 2016, 7, 24.

[13] Pentcheva-Hoang, T., Corse, E., Allison, J. P.: Negative regulators of T-cell activation: potential targets for therapeutic intervention 
in cancer, autoimmune disease, and persistent infections. Immunol. Rev., 2009, 229(1), 67-87.

[14] Butte, M. J., Keir, M. E., Phamduy, T. B.: PD-L1 interacts specifically with B7-1 to regulate T cell function. J. Immunol., 2007, 178 (Meeting Abstract), S143.

[15] Francisco, L. M., Salinas, V. H., Brown, K. E., et al.: PD-L1 regulates the development, maintenance, and function of induced regulatory T cells. J. Exp. Med., 2009, 206(13), 3015-3029.

[16] Inman, B. A., Frigola, X., Dong, H., et al.: Costimulation, coinhibition and cancer. Curr. Cancer Drug Targets, 2007, 7(1), 15-30.

[17] Vignali, D. A., Collison, L. W., Workman, C. J.: How regulatory T cells work. Nat. Rev. Immunol., 2008, 8(7), 523-532.

[18] Corthay, A.: How do regulatory T cells work? Scand. J. Immunol., 2009, 70(4), 326-336.

[19] Larsen, S. K.: Cellular immune responses towards regulatory cells. Dan. Med. J., 2016, 63(1), B5188.

[20] Markenson, J. A., Gibofsky, A., Palmer, W. R., et al.: Persistence with anti-tumor necrosis factor therapies in patients with rheumatoid arthritis: observations from the RADIUS registry. J. Rheumatol., 2011, 38(7), 1273-1281.

[21] Daïen, C. I., Morel, J.: Predictive factors of response to biological disease modifying antirheumatic drugs: towards personalized medicine. Mediators Inflamm., 2014, 2014, Article ID 386148.
[22] Vincent, F. B., Morand, E. F., Murphy, K., et al.: Antidrug antibodies $(\mathrm{ADAb})$ to tumour necrosis factor (TNF)-specific neutralising agents in chronic inflammatory diseases: a real issue, a clinical perspective. Ann. Rheum. Dis., 2013, 72(2), 165-178.

[23] Benucci, M., Li Gobbi, F., Meacci, F., et al.: Antidrug antibodies against TNF-blocking agents: correlations between disease activity, hypersensitivity reactions, and different classes of immunoglobulins. Biologics, 2015, 9, 7-12.

[24] Armand, P.: Immune checkpoint blockade in hematologic malignancies. Blood, 2015, 125(22), 3393-3400.

[25] Sunshine, J., Taube, J. M.: PD-1/PD-L1 inhibitors. Curr. Opin. Pharmacol., 2015, 23, 32-38.

[26] Henick, B. S., Herbst, R. S., Goldberg, S. B.: The PD-1 pathway as a therapeutic target to overcome immune escape mechanisms in cancer. Expert Opin. Ther. Targets, 2014, 18(12), 1407-1420.

[27] Kobold, S., Duewell, P., Schnurr, M., et al.: Immunotherapy in tumors: Activated $\mathrm{T}$ cells as a new treatment modality. Dtsch. Arztebl. Int., 2015, 112(48), 809-815.

[28] Brabmer, J. R., Hammers, H., Lipson, E. J.: Nivolumab: targeting PD-1 to bolster antitumor immunity. Future Oncol., 2015, 11(9), 1307-1326.

(Sütő Gábor dr., Pécs, Akác u. 1., 7635 e-mail: gabor.suto@immunologus.hu) 